\title{
Amino Acid Digestibility of Feed Ingredients in Cecectomized Adult Roosters
}

http://dx.doi.org/10.1590/1806-9061-2018-0924

-Author(s)

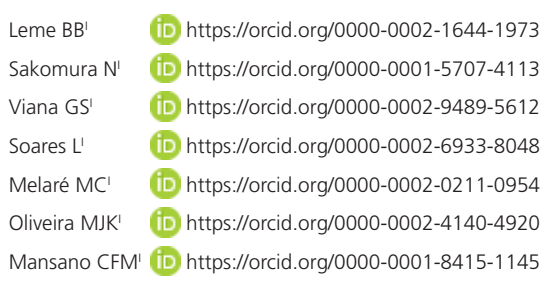

Faculdade de Ciências Agrárias e Veterinárias, Universidade Estadual Paulista "Júlio de Mesquita Filho", 14884-900, Jaboticabal, São Paulo, Brazil.

\section{-Mail Address}

Corresponding author e-mail address Nilva Kazue Sakomura

Via de acesso Professor Paulo Donato Castellane, s/n, 14884-900 - Jaboticabal,

São Paulo, Brasil.

Phone: + 551632097503

Email: mail.gsviana@gmail.com

\section{aKeywords}

Cecectomized, digestible amino acids, poultry.

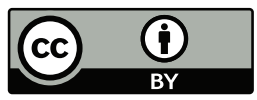

Submitted: 16/October/2018 Approved: 25/February/2019

\section{ABSTRACT}

A digestibility assay was conducted in order to determine the digestibility coefficients (DC) of amino acids of feed ingredients in cecectomized adult roosters. In total 48 cecectomized adult roosters were used to assess the coefficient of digestibility of 7 ingredients: corn, soybean meal, soybean concentrate, corn gluten meal, wheat bran, peanut meal, and feather meal. Each ingredient was replicated six times and a group of 6 rooster was used to measure endogenous amino acid losses. After 48 hours of fasting, the roosters were tube fed $20 \mathrm{~g}$ of ingredients tested twice during a day. At 12 hour-intervals excreta and endogenous losses were collected and immediately freezedried for further chemical analysis. At the end of the assay, excreta were weighed and samples of ingredients, excreta, and endogenous losses were pooled and analysed for dry matter, nitrogen and amino acid content. The coefficients of indispensable amino acids for the most feed ingredients assessed in the current research were similar to published literature like AMINODat ${ }^{\oplus 5.0}$ and the $4^{\text {th }}$ edition of the Brazilian Tables for Poultry and Swine, except feather meal, in which only digestible Trp and Thr content were similar to literature. Particularly, the coefficients for some amino acids like Arg and Gly exhibited large discrepancies from literature in almost all the feed ingredients assessed herein. In general, using cecectomized adult roosters proved to be a reliable technique to assess the digestibility of feed ingredients used in poultry diets.

\section{INTRODUCTION}

Feed cost represents the largest fraction of final production costs, though matching as closely as possible the supply of nutrients and nutritional requirements is essential for achieving maximum economic and environment efficiency (Van Milgen et al., 1998). Protein is universally recognized as the most expensive nutrient in poultry diets so practical diets have increasingly been formulated to provide specific levels of digestible amino acids. The biological value of a given protein may be determined either by the pattern of its amino acids or how available and digestible such amino acids are to be used by the organism for maintenance purposes and body protein accretion.

Poultry industry most often formulates practical diets based on corn and soybean meal. Nonetheless, depending on the spread in the price of both feed ingredients, a wide array of alternative ingredients, may be, and, are indeed used by nutritionists with the objective of reducing final feed cost. Such ingredients differ markedly from each other with respect to the fraction of undigested amino acid contents. Despite widespread, the reliance on including alternative ingredients in practical diets requires a solid database about digestibility coefficients of amino acids in ingredients, which consequently requires digestibility 
Leme BB, Sakomura N, Viana GS, Soares L, Melaré MC, Oliveira MJK, Mansano CFM

\section{Amino Acid Digestibility of Feed Ingredients in Cecectomized Adult Roosters}

researches. When considering incorrect coefficients to formulate diets, lower will be the efficiency with which dietary protein will convert into final food products (Fernandez et al., 1995, Leme et al., 2004). Evidences suggest that diets formulated marginally deficient in amino acids or protein reduces the uniformity of performance and carcass trait responses in commercial broiler flocks, leading to reduced revenue (Duncan, 1988, Lemme, 2003, Berhe \& Gous, 2008, Bendezu et al., 2018).

Over the years of digestibility researches, the use of adult male cockerels, after the surgical ceca removal Parsons (1986) proved to be convenient and reproducible since the fraction of dietary undigested amino acids were not susceptible to hindgut fermentation (Rostagno et al., 1995, Johnson et al., 1998, Fastinger et al., 2006). From time to time, feed tables containing values of amino acid digestibility are updated, which reinforces the need of digestibility researches to build a reliable database of digestibility coefficients of amino acids. Given this background, the current research was conducted to establish the true digestibility of amino acids in feed ingredients in cecectomized adult roosters.

\section{MATERIAL AND METHODS}

The assay was conducted in the Laboratory of Poultry Sciences of the Universidade Estadual Paulista Júlio de
Mesquita Filho, Jaboticabal, São Paulo, Brazil. All the procedures described in this paper were previously approved by the institutional committee of animal care and use of the Universidade Estadual Paulista Júlio de Mesquita Filho.

\section{Birds and experimental design}

In total forty-eight Hy-Line adult roosters were cecectomized at 56 weeks of age according to Pupa et al. (1998). At 60 weeks of age the roosters (average body weight of $2,242 \mathrm{~g} \pm 169 \mathrm{~g}$ ) were housed in an environmentally controlled room in individual raised wire cages ( $40 \mathrm{~cm}$ long $\times 50 \mathrm{~cm}$ wide $\times 60 \mathrm{~cm}$ high). Birds were deprived of feed for 48 hours to ensure that gastrointestinal tract was completely empty at the beginning of the assay. For the first 48 hours of fasting period, birds were given daily $60 \mathrm{ml}$ of a solution of sucrose and water (50\%) (Sakomura \& Rostagno, 2016). After the fasting period, roosters were tube fed $20 \mathrm{~g}$ twice a day as described by Sakomura \& Rostagno (2016) of eight different feed ingredients: corn, soybean meal, soybean concentrate, corn gluten meal, wheat bran, peanut meal, and feather meal. Additionally, a group of roosters were fasted throughout 48 hours in order to determine endogenous amino acid losses. Each ingredient tested had six replicates, as well as fasted rooster group. Excreta samples and endogenous losses were collected for 48 hours in 12 hours-intervals and immediately freeze-dried in order to avoid nitrogen losses.

Table 1 - Analyzed composition (\%) of the feed ingredients (as-fed basis).

\begin{tabular}{|c|c|c|c|c|c|c|c|}
\hline Item & Corn & Corn gluten meal & Wheat bran & Soybean meal & Soybean concentrate & Peanut meal & Feather meal \\
\hline Dry matter & 87.0 & 91.1 & 87.1 & 88.2 & 92.2 & 91.5 & 95.7 \\
\hline Crude protein & 8.68 & 63.9 & 15.2 & 46.5 & 59.2 & 42.7 & 83.2 \\
\hline \multicolumn{8}{|c|}{ Indispensable amino acids } \\
\hline Methionine & 0.16 & 1.63 & 0.22 & 0.57 & 0.75 & 0.56 & 1.78 \\
\hline Lysine & 0.27 & 1.14 & 0.62 & 3.01 & 3.98 & 1.9 & 2.19 \\
\hline Threonine & 0.28 & 2.19 & 0.47 & 1.87 & 2.41 & 1.33 & 4.11 \\
\hline Valine & 0.42 & 3.02 & 0.73 & 2.29 & 3.23 & 1.96 & 7.98 \\
\hline Isoleucine & 0.3 & 2.67 & 0.49 & 2.12 & 2.83 & 1.31 & 4.25 \\
\hline Arginine & 0.42 & 2.09 & 1.03 & 3.23 & 4.22 & 5.06 & 5.74 \\
\hline Tryptophan & 0.06 & 0.25 & 0.27 & 0.56 & 0.8 & 0.42 & 0.48 \\
\hline Leucine & 1.09 & 9.87 & 0.91 & 3.59 & 4.69 & 2.41 & 6.85 \\
\hline Phenylalanine & 0.38 & 3.92 & 0.56 & 2.27 & 2.98 & 2.24 & 4.24 \\
\hline Histidine & 0.25 & 1.40 & 0.38 & 1.22 & 1.55 & 1.17 & 1.04 \\
\hline \multicolumn{8}{|c|}{ Dispensable amino acids } \\
\hline Alanine & 0.66 & 5.75 & 0.73 & 2.08 & 2.54 & 1.67 & 4.18 \\
\hline Cysteine & 0.13 & 0.59 & 0.27 & 0.71 & 0.87 & 0.63 & 2.45 \\
\hline Tyrosine & 0.31 & 3.29 & 0.48 & 1.67 & 2.01 & 1.22 & 2.62 \\
\hline Glycine & 0.32 & 1.85 & 0.77 & 2.03 & 2.59 & 1.74 & 6.63 \\
\hline Serine & 0.43 & 3.61 & 0.68 & 2.56 & 3.26 & 1.91 & 10.15 \\
\hline Proline & 0.84 & 5.82 & 1.02 & 2.42 & 3.15 & 1.63 & 7.81 \\
\hline Glutamic acid & 1.68 & 13.5 & 3.15 & 8.91 & 11.45 & 9.05 & 8.68 \\
\hline Aspartic acid & 0.72 & 3.49 & 1.21 & 6.7 & 8.09 & 4.55 & 4.84 \\
\hline
\end{tabular}


Leme BB, Sakomura N, Viana GS, Soares L, Melaré MC, Oliveira MJK, Mansano CFM

\section{Amino Acid Digestibility of Feed Ingredients in Cecectomized Adult Roosters}

\section{Chemical analysis}

Chemical analysis of feed ingredients, excreta and endogenous losses were performed according to AOAC (2005). All the samples were pooled and analyzed for dry matter (method 920.39), nitrogen (Foss Kjeltec 8400, method 2001.11), and amino acid content (High Performance Liquid Chromatography). True digestibility coefficients of amino acids were calculated according to Sakomura \& Rostagno (2016) as follows:

$\operatorname{TDC}(\%)=(($ AAin $-($ AAexc - AAend $))) /($ AAin $) \times 100$ where AAin is the intake of the amino acid; AAexc is the content of amino acid in excreta; AAend is the content of amino acid in endogenous losses.

\section{RESULTS AND DISCUSSION}

The calculated true ileal digestibility coefficients of amino acids of the eight feed ingredients are detailed in Table 2. Except for Thr, Arg and Phe, whose digestibility coefficients exceeded the margin of $5 \%$ of difference from the coefficients provided by Rostagno et al. (2017) and/orAMINODat ${ }^{\circledR 5} .0$ feed database, all the indispensable amino acids of soybean meal exhibited digestibility coefficients similar to both references. For soybean concentrate, among the digestibility coefficients determined in roosters for the indispensable amino acids Phe, lle and Trp exceeded in $9,8,6 \%$ the coefficients provided by Rostagno et al. (2017) for these amino acids, respectively. In general, the coefficients for indispensable amino acids in soybean concentrate determined in roosters was very close to those described by AMINODat $^{\circledR} 5.0$, except for Met, whose digestibility was $6 \%$ higher than that provided by the aforementioned feed database. The same pattern was noticed for corn gluten meal, whose coefficients found for indispensable amino acids were similar to those described by AMINODat ${ }^{\circledR 5} .0$ except for Trp, whose digestibility was approximately 13\% lower in the cecectomized roosters (90.5 vs. $79.1 \%$ ). Conversely, when a comparison is made between the digestibility coefficients for corn gluten meal reported by Rostagno et al. (2017) with those found in the current assay, the outcomes showed higher values in cecectomized roosters for Lys (89.0 vs. 80\%), Val (94.8 vs. $87 \%)$, Phe (98.2 vs. $91 \%), \operatorname{Arg}(95.7$ vs. $89.0 \%)$, lle (83.1 vs. $70.1 \%$ ) and His (65.1 vs. $59.0 \%$ ).

For corn, true digestibility coefficients determined in roosters for Argwere 9 and 7\% higher than those reported by Rostagno et al. (2017) and AMINODat ${ }^{\circledR 5} 5.0$ feed database, respectively. Despite similar to Rostagno et al. (2017), digestibility coefficients of Lys and Phe in corn exceeded in 11 and $7 \%$ the values provided by AMINODat ${ }^{\circledR 5}$.0. The coefficients for Trp in corn determined with roosters were markedly higher than the value suggested by Rostagno et al. (2017) (92.6 vs. $83 \%$ ), even though this difference was lower than $1 \%$ when a comparison is made withAMINODat ${ }^{\circledR} 5.0$ coefficient. Except for Lys and Trp, the digestibility coefficients determined for indispensable amino

Table 2 - True ileal digestibility coefficients (\%) of amino acids for feed ingredients in cecectomized adult roosters.

\begin{tabular}{|c|c|c|c|c|c|c|c|}
\hline Item & Corn & Corn gluten meal & Wheat bran & Soybean meal & Soybean concentrate & Peanut meal & Feather meal \\
\hline \multicolumn{8}{|c|}{ Indispensable amino acids } \\
\hline Methionine & 94.7 & 95.7 & 82.8 & 89.2 & 89.6 & 91.8 & 69.1 \\
\hline Lysine & 92.9 & 89.0 & 85.0 & 90.6 & 89.1 & 86.1 & 71.1 \\
\hline Threonine & 93.3 & 93.0 & 78.5 & 89.0 & 88.8 & 86.8 & 76.3 \\
\hline Valine & 90.7 & 94.8 & 76.8 & 89.3 & 91.7 & 90.8 & 87.3 \\
\hline Isoleucine & 93.8 & 94.7 & 81.6 & 92.2 & 92.3 & 89.5 & 87.0 \\
\hline Arginine & 97.8 & 95.7 & 84.5 & 82.9 & 91.0 & 79.5 & 85.4 \\
\hline Tryptophan & 94.6 & 79.1 & 87.7 & 86.6 & 91.3 & 86.6 & 70.6 \\
\hline Leucine & 96.5 & 97.9 & 80.6 & 92.0 & 92.4 & 91.4 & 82.9 \\
\hline Phenylalanine & 97.5 & 98.2 & 88.0 & 94.7 & 94.9 & 95.8 & 86.3 \\
\hline Histidine & 95.6 & 93.7 & 78.5 & 87.4 & 87.5 & 84.3 & 65.1 \\
\hline \multicolumn{8}{|c|}{ Dispensable amino acids } \\
\hline Alanine & 95.0 & 97.2 & 78.3 & 89.0 & 88.8 & 88.6 & 83.1 \\
\hline Cysteine & 92.6 & 77.7 & 88.0 & 86.5 & 84.8 & 85.5 & 59.5 \\
\hline Tyrosine & 88.9 & 95.9 & 73.9 & 88.5 & 90.2 & 87.5 & 79.4 \\
\hline Glycine & 70.1 & 78.9 & 61.2 & 60.7 & 71.3 & 48.7 & 73.7 \\
\hline Serine & 93.9 & 95.7 & 85.2 & 92.8 & 92.0 & 86.1 & 81.9 \\
\hline Proline & 96.6 & 96.3 & 86.8 & 92.6 & 92.5 & 89.1 & 71.9 \\
\hline Glutamic acid & 95.4 & 96.9 & 91.9 & 95.0 & 94.0 & 95.0 & 74.7 \\
\hline Aspartic acid & 95.6 & 93.6 & 84.8 & 93.8 & 90.4 & 90.0 & 51.3 \\
\hline
\end{tabular}


Leme BB, Sakomura N, Viana GS, Soares L, Melaré MC, Oliveira MJK, Mansano CFM

\section{Amino Acid Digestibility of Feed Ingredients in Cecectomized Adult Roosters}

acids in wheat bran were similar to those reported by Rostagno et al. (2017) and AMINODat ${ }^{\circledR} 5.0$, even though the values determined with roosters were slightly higher than those described by both literature. For peanut meal, only the coefficients determined with roosters for Arg, Lys, and Met differed by $\pm 5 \%$ from the values described by Rostagno et al. (2017) and AMINODat ${ }^{\circledR 5.0}$. Among the feed ingredients assessed in the current assay, feather meal was that, whose digestibility coefficients for indispensable amino acids exhibited the most pronounced discrepancies compared with literature. For this ingredient, only the coefficients determined for Trp and Thr were similar the Rostagno et al. (2017) and/or AMINODat ${ }^{\circledR} 5.0$, whilst all the other indispensable amino acids had differences, which exceed the margin of $5 \%$ of difference from both literatures.

The feed ingredients, whose digestibility coefficients for dispensable amino acids exhibited less differences from literature were soybean meal, corn gluten meal, and soybean concentrate. For soybean meal, the coefficient found in the current research for Gly differed markedly from AMINODat ${ }^{\circledR} 5.0$ coefficient, whilst for soybean concentrate, the coefficient determined for Cys was not in accordance with the above referred literature. The coefficient determined for Ser in soybean concentrate was 10\% lower than that provided byAMINODat ${ }^{\circledR} 5.0$. For peanut meal, the coefficients for Asp and Cys exceeded in 8\% (92 vs. 85\%) and $10 \%(85.5$ vs. $77 \%)$ the values of digestibility provided by AMINODat ${ }^{\circledR 5} 5.0$ for both amino acids, respectively. The coefficient for Gly in peanut meal was almost 2 times lower than that described by AMINODat ${ }^{\circledR 5}$.0. For corn, only the coefficients determined for Glu and Pro were similar to AMINODat ${ }^{\circledR 5.0}$, whilst for feather meal the unique coefficients close to such literature were those determined for Ala, Cys, and Ser.

Overall, the coefficients determined in the current research for both dispensable and indispensable amino acids were similar to published literature, with some few exceptions. These differences between our outcomes and the databases above mentioned may be attributed to the method by which digestibility was determined, the cereal variety, and soil conditions (Fan et al., 1996). Parsons et al. (1992) suggest that excessive heat during the drying process may also affect amino acid digestibility in feed ingredients due to Maillard reaction occurrence. According to such authors, depending on its extent, Maillard reactions may lead Lys to be irreversibly bound to a carbohydrate moiety or converted to other compounds. As pointed out by
Moughan \& Rutherfurd (1996), in both frameworks, birds do apparently not use Lys, but part of bound Lys could be released during acid hydrolysis and therefore analyzed as Lys in the ingredients, excreta or digesta samples. Evans \& Butts (1948) suggests that excessive heat can also lead to complexes between amino acids and dietary fiber, which in turn could decrease digestibility coefficients. For animal meals, beyond the processing procedures, the digestibility coefficients of amino acids may also be influenced by the source and proportion of raw materials like bones, viscera, meat, blood and feathers (Bellaver et al., 1997).

The endogenous losses of proteinaceous material from gut can be divided into nonspecific losses, which reflect the losses of amino acids not influenced by diets or feed ingredients, and those classified as diet-specific losses, whose values are related to the characteristics of the diet or feed ingredient under study (Jondreville et al., 1995, Boisen, 1998) like the presence of fibers and their characteristics (e.g. lignine content, solubility, etc.)and antinutritional factors (Schulze et al., 1994, Le Guen et al., 1995, Leterme et al., 1996). The main sources of endogenous nitrogen from gut include salivary, gastric, pancreatic, bile, and small intestinal secretions and sloughed mucosal cells, in which secretions from the small intestinal and pancreas represent the major fraction of the total secretions (Souffrant, 1991). Even though either fasting adult roosters or feeding broilers a protein-free diet have been the most commonly approaches to determine endogenous amino acid losses in chicks, both methods of measuring digestibility are criticized once the endogenous losses are influenced by dietary protein, fiber and antinutritional factors (Parsons et al., 1982, Parsons, 1984, Sauer \& Ozimek, 1986, Chung \& Baker, 1992).

In the current research, endogenous losses of amino acids were measured using fasted adult roosters. When a comparison is made between values of endogenous amino acid losses from fasted roosters and birds fed protein-free diets, greater fecalamino acid excretion is expected in birds fed protein-free diets due to a higher mucus production (Parsons et al., 1983, Chung \& Baker, 1992). When comparing with published literature, Chung \& Baker (1992) reported lower-than expected digestibility of amino acids in feed ingredients using cecectomized adult roosters. However, except for a few amino acids, the coefficients determined herein were very similar to those described by the $4^{\text {th }}$ edition of the Brazilian Tables for Poultry and Swine (Rostagno et al., 2017) and by the AMINODat ${ }^{\circledR 5}$.0. 
Leme BB, Sakomura N, Viana GS, Soares L, Melaré MC, Oliveira MJK, Mansano CFM

\section{Amino Acid Digestibility of Feed Ingredients in Cecectomized Adult Roosters}

The outcomes found in the current research provided clear evidences that the use of cecectomized roosters proved to be effective in estimating digestibility coefficients of amino acids in poultry. The coefficients determined in the current study can be used in the future to update feed tables of ingredient nutritional composition, which would contribute to match as closely as possible the dietary supply of nutrients and bird nutritional requirements.

\section{ACKNOWLEDGEMENTS}

We would like to acknowledge FAPESP (process 2013/25761-4) who financed this research.

\section{REFERENCES}

AminoDat ${ }^{\circledR}$ 5.0 Animal nutritionist's information edge. Essen: Evonik Nutrition and Care $\mathrm{GmbH} ; 2016$

AOAC -Association of Official Analytical Chemists. Official methods of analysis. $16^{\text {th }}$ ed. Washington; 2005.

Behre ET, Gous RM. Effect of dietary protein content on growth, uniformity and mortality of two commercial broiler strains. South African Journal of Animal Science 2008;38(4):293-302.

Bellaver C, Easter RA, Parsons C, Guidoni AL. Prediction equations for protein and amino acid digestibility in meat and bone meals. European Association for Animal Production 1997;88:426-429.

Bendezu HCP, Sakomura, NK, Malheiros, EB, Gous, RM, Ferreira, NT, Fernandes, JBK. Modelling the egg components and internal cycle length of laying hens. Animal Production Science 2018;59(3):420-426.

Boisen S, Verstegen MWA. Evaluation of feedstuffs and pig diets. Energy or nutrient-based evaluation systems? II. proposal for a new nutrientbased evaluation system. Acta Agriculturae Scandinavica A. Animal Sciences 1998;48(2):95-102.

Chung TK, Baker DH. Apparent and true amino acid digestibility of a crystalline amino acid mixture and of casein: Comparison of values obtained with ileal-cannulated pigs and cecectomized cockerels. Journal Animal Science 1992;70:3781-3780.

Evans RJ, Butts HA. Studies on the heat inactivation of lysine in soy bean oil meal. Journal of Biological Chemistry 1948;175:15-20.

Fan J, Mitchell JR, Blanshard JMV. The effect of sugars on the extrusion of maize grits: II. Starch conversion. International Journal of Food Science \& Technology 1996;31(1):67-76.

Fastinger ND, Latshaw JD, Mahan DC. Amino acid availability and true metabolizable energy content of corn distiller's dried grains with solubles in adult cecectomized roosters. Poultry Science $2006 ; 85: 1212$ 1216.

Fernandez SR, Zhang Y, Parsons CM. Dietary formulation with cottonseed meal on a total amino acid versus a digestible amino acid basis. Poultry Science 1995;74:1168-1179

Johnson ML, Parsons CM, Fahey Jr GC, Merchen NR, Aldrich CG. Effects of species raw material source, ash content, and processing temperature on amino acid digestibility of animal by-product meals by cecectomized roosters and ileally cannulated dogs. Journal Animal Science 1998;76:1112-1122.
Jondreville C, Van Den Broecke J, Gatel F, Van Cauwenberghe S. Ileal digestibility of amino acids in feedstuffs for pigs. Paris: Eurolysine/ITFC Publication; 1995

Le Guen MP, Huisman J, Guéguen J, Beelen G, Verstegen MWA. Effects of a concentrate of pea antinutritional factors on pea protein digestibility in piglets. Livestock Production Science 1995;44(2):157-167.

Lemme A. The "Ideal Protein Concept" in broiler nutrition 1. Methodological aspects-opportunities and limitations. Degussa AG Amino News 2003;4:7-14.

Lemme A, Ravindran V, Bryden, WL. Ileal digestibility of amino acids in feed ingridients for broilers. World's Poultry Science Journal 2004;60(4):423438.

Leterme $\mathrm{P}$, Seve $\mathrm{b}$, Thewis A, Moransi P. Effect of oral and Parenteral nutrition vs. N-Free nutrition on the endogenous amino acid flow at the ileum of the pig. Journal Science Food Agriculture 1996;71:265-271.

Moughan PJ, Rutherfurd SM. A new method for determining digestible reactive lysine in foods. Journal of Agricultural and Food Chemistry 1996;44(8):2202-2209.

Parsons CM, Hashimoto K, Wedekind KJ, Han Y, Baker DH. Effect of overprocessing on availability of amino acids and energy in soybean meal. Poultry Science 1992;71(1):133-140.

Parsons CM, Baker DH, Harter JM. Distillers dried grains with solubles as a protein source for the chick. Poultry Science 1983;62(12):2445-2451.

Parsons CM, Potter LM, Brown JRD. Effects of dietary protein and intestinal microflora on excretion of amino acids in poultry. Poultry Science 1982;61: 939-946.

Parsons CM. Influence of caecectomy and source of dietary fibre or starch on excretion of endogenous amino acids by laying hens. British Journal of Nutrition 1984;51(3):541-548.

Pupa JMR, Leão MI, Carvalho AU, Pompermayer LG, Rostagno HS. Cecectomia em galos sob anestesia local e incisão abdominal. Arquivo Brasileiro de Medicina Veterinária e Zootecnia 1998;50(5):531-535.

Rostagno HS, Albino LFT,Hannas MI, Donzele JL, Sakomura NK, Perazzo FG, et al. Tabelas brasileiras para aves e suínos. Composição de alimentos e exigências nutricionais. $4^{\text {th }}$ ed. Viçosa: UFV; 2017.

Rostagno HS, Pupa JMR, Pack M. Diet formulation for broilers based on total versus digestible amino acids. Journal of Applied Poultry Research 1995;4(3):293-299

Sakomura NK, Rostagno HS. Métodos de pesquisa em nutrição de monogástricos. $2^{\text {nd }}$ ed. Jaboticabal: Funep; 2016.

Sauer WC, Ozimek L. Digestibility of amino acids in swine: results and their practical applications. A review. Livestock Production Science 1986;15(4):367-388.

Schulze E, Kelliher FM, Korner C, Lloyd J, Leuning R. Relationships among maximum stomatal conductance, ecosystem surface conductance, carbon assimilation rate, and plant nitrogen nutrition: a global ecology scaling exercise. Annual Review of Ecology and Systematics 1994;25(1):629-662.

Sibbald IR. A bioassay for true metabolizable energy in feedingstuffs. Poultry Science 1976;55(2):303-308.

Souffrant WB. Endogenous nitrogen losses during digestion in pigs. Proceedings of the $5^{\text {th }}$ International Symposium, 1991; Wageningen. Holanda. Wageningen Academic Publishers; 1991.

Parsons CM. Determination of digestible and available amino acids in meat meal using conventional and caecectomized cockerels or chick growth assays. British Journal of Nutrition 1986;56:227-240.

Van Milgen J, Bernier JF, Lecozler Y, Dubois S, Noblet J. Major determinants of fasting heat production and energetic cost of activity in growing pigs of different body weight and breed/castration combination. British Journal of Nutrition 1998;79(6):509-517. 
